\title{
STUDIES OF GONOCOCCAL INFECTION. IV. THE EFFECT OF MUCIN ON THE BACTERIOLYTIC POWER OF WHOLE BLOOD AND IMMUNE SERUM
}

\author{
By CHESTER S. KEEFER AND WESLEY W. SPINK \\ (From the Thorndike Memorial Laboratory, Second and Fourth Medical Services \\ (Harvard), Boston City Hospital, and the Department of Medicine, Harvard \\ Medical School, Boston)
}

(Received for publication July 13, 1937)

The primary lesion in gonococcal infection is determined by the portal of entry and by the ability of the gonococcus to survive in the given environment. The spread of infection from the primary lesion may be directly along the mucous membrane, by the lymphatics, or by the blood stream. Once the organisms enter the circulating blood they are cleared rapidly. Commonly, they focalize in the joints or tendon sheaths where they are able to survive. One of the important problems in gonococcal arthritis is the determination of the factors which favor the localization of the organisms in the joints and tendon sheaths. At the moment, there exists very little information regarding the factors controlling the selective localization of bacteria. It seems likely, however, that biochemical differences in organisms, as well as differences in the chemical composition of the various tissues and tissue fluids, must play a most important part. That is to say, certain organisms localize and survive in tissues which are peculiarly favorable for their growth, and this is determined in part by the chemical reactions of the environment.

Since the gonococcus usually thrives in areas which are supplied by large amounts of mucus, such as the urethra, vagina, conjunctivae, the joints, and the tendon sheaths, it was suggested that mucin might be a factor in determining the localization of organisms in the various tissues.

Moreover, in the preceding paper (1) it was shown that the synovial fluid from some patients with gonococcal arthritis was actively bactericidal for the homologous strain of the gonococcus. When the fluid was infected, no antibodies could be demonstrated in spite of the fact that the whole blood from the same patients contained antibodies. When the synovial fluid was sterile, it was actively bactericidal for the homologous strains of organism. Inasmuch as synovial fluid is an exudation of blood plasma with the addition of mucin, it was of considerable interest to us to determine whether or not the presence of mucin influenced the growth of gonococci when antibodies were present.

Miller and Castles (2) have reported a method for the production of experimental meningococcal infection in the peritoneal cavity of the mouse. They have demonstrated that the presence of mucin enhanced the invasiveness of the organisms by local interference with the defense mechanism of the host. More recently, Fothergill, Dingle, and Chandler (3) have demonstrated fatal infections in mice with mucin suspensions of smooth strains of $H$. influenzae. In addition, Nungester, Jourdonais, and Wolf (4) have stated that mucin inhibits the bactericidal properties of phagocytic cells and, in this way, enables grampositive organisms to survive in the body of the host for longer periods of time. They also pointed out that mucin seemed to aid some organisms in their growth in vitro.

In the light of the above observations, it seems clear that mucin causes a rupture of the local defense mechanism against certain organisms to which experimental animals are normally resistant. This change in resistance was brought about by altering the environment in which the organisms were placed.

In our previous studies $(5,6)$, it was ascertained that gonococci were killed in vitro by lysis and that, during gonococcal infection, bacteriolysins increased in the whole defibrinated blood. In the present investigation, we were concerned with studying the effect of adding mucin to various samples of human and rabbit blood, and antigonococcal serum. The immediate purpose of these experiments was to determine whether mucin was capable of altering the bacteriolytic 
action of the whole blood or of antigonococcal serum in vitro.

\section{METHODS}

The mucin was obtained from the same source as described by Miller and Castles (2) in their studies on experimental meningococcal infections. ${ }^{1}$ The mucin suspensions were made up with a slight variation from the method of Miller, as follows. Enough physiological saline solution was poured onto a weighed quantity of mucin to moisten it thoroughly. After standing for about 30 minutes, the sticky mass was stirred and rubbed free of solid lumps. Stirring was continued while enough saline solution was added to obtain the desired concentrations (1,2, and 5 per cent). The suspension was placed in a flask and autoclaved at a 15 pound pressure for 15 minutes. After cooling, the reaction was adjusted with normal sodium hydroxide at a $\mathrm{pH}$ of 7.5 , and tested for sterility.

The bactericidal titer of whole defibrinated blood for the gonococcus with and without the addition of mucin was determined as described in the previous paper (5). Five-tenths cubic centimeter of whole, defibrinated blood with 0.1 cc. of a suspension of organisms were used. Varying concentrations of the mucin suspension were tried, including 1,2 , and 5 per cent dilutions. Practically the same results were obtained with these different concentrations. To standardize the results, a 5 per cent concentration of mucin was used, adding $0.15 \mathrm{cc}$. of a 5 per cent suspension to $0.5 \mathrm{cc}$. of whole, defibrinated blood and $0.1 \mathrm{cc}$. of organisms which made the concentration of the mucin approximately one per cent.

The complement of the blood serum was titrated before and after the addition of mucin. Sensitized sheep cells were used with varying amounts of blood serum according to the usual technique of titrating complement.

\section{The effect of mucin alone on the growth of the gonococcus}

The first experiment that engaged our attention was planned to determine whether mucin

\footnotetext{
1 Sold under the name of "Granular Mucin" by the Wilson Laboratories, Chicago.
}

alone would support the growth of the gonococcus in vitro.

A series of small, pyrex glass tubes containing $0.5 \mathrm{cc}$. of a 5 per cent suspension of mucin and $0.1 \mathrm{cc}$. of a broth suspension of gonococci were sealed in a gas-oxygen flame and rotated in the incubator. A similar series of tubes containing $0.5 \mathrm{cc}$. whole defibrinated blood and $0.1 \mathrm{cc}$. organisms was likewise sealed and rotated. At hourly intervals, a tube containing mucin and organisms, and one of blood and organisms were opened and the contents cultured. Organisms could not be cultured from the blood at the end of 4 hours. However, the organisms were present in the tubes containing mucin alone as long as 28 hours after inoculation. After this time, they could not be found. This experiment indicated that the bacteriolytic action of whole blood asserted itself within 4 hours after being mixed with the organisms, whereas the organisms survived in the mucin a longer period of time and died out slowly. We inclined to the belief that this was perhaps due to the lack of material necessary to support continuous growth.

To test whether the organisms survived in the mucin because of the presence of nutrient material contained in the broth in which the organisms were suspended, a second experiment was carried out with organisms added to a mucin suspension without the presence of broth. Two strains were studied. Several loopfuls of each were removed from a blood-agar plate and suspended in $5 \mathrm{cc}$. of a 5 per cent solution of mucin in test tubes. The tubes were placed in a candle jar at $38^{\circ} \mathrm{C}$., and every 8 to 12 hours, $0.2 \mathrm{cc}$. of the suspension of mucin and organisms was transferred to fresh tubes of mucin, and about $1 \mathrm{cc}$. to tubes containing blood broth. The purpose of this was to test the viability of the organisms. This procedure reduced the possibility of the transfer of some of the original broth media to a minimum, and it served to determine whether the addition of fresh mucin provided new material for growth. There was no appreciable difference in the length of time in which living organisms could be maintained in mucin by this method. No organisms were recovered after 32 hours. It is clearly evident, then, that mucin alone is a poor culture medium for the continuous growth of the gonococcus. This has been shown 
to be the case for the meningococcus as well as the gonococcus by Miller (7). It is well worth remembering, however, that gonococci can survive in mucin alone at body temperature for at least 28 to 32 hours. This period of survival is probably an aid in establishing infection.

The effect of adding mucin to whole defibrinated blood

To compare the bacteriolytic titer of fluids containing mucin with those without mucin, the whole blood from patients with gonococcal arthritis and from normal individuals was studied with and without the addition of mucin. Mucin was added to the blood so that its content would be one per cent. This is approximately the amount found in the synovial fluid in some cases of gonococcal arthritis.

The results are shown in Figure 1. The black dots represent the maximum number of gonococci killed by $0.5 \mathrm{cc}$. of blood from the various individuals tested. The circles indicate the max- imum number following the addition of mucin. When the mucin was added, it was common to find that bacteriolysis was reduced. There were a few exceptions but, even so, in all instances the maximum number of organisms killed by the blood without the addition of mucin was small, so that it was impossible to show that mucin had any effect one way or the other in such cases.

It was desirable to know whether media other than mucin would inhibit the bacteriolytic effect of whole blood on the gonococcus. Thus, the following experiment was done. Fifteen-hundredths cubic centimeter of veal infusion broth was added to one series of tubes with blood and organisms, $0.15 \mathrm{cc}$. of a 5 per cent concentration of mucin to another, and a third series served as a control with only blood and organisms. The evidence presented in Table I reveals that the addition of broth had no inhibitory effect on the bactericidal effect of whole blood.

Summing up these experiments, it is clearly evident that the addition of mucin to whole blood containing bacteriolysins frequently reduces its

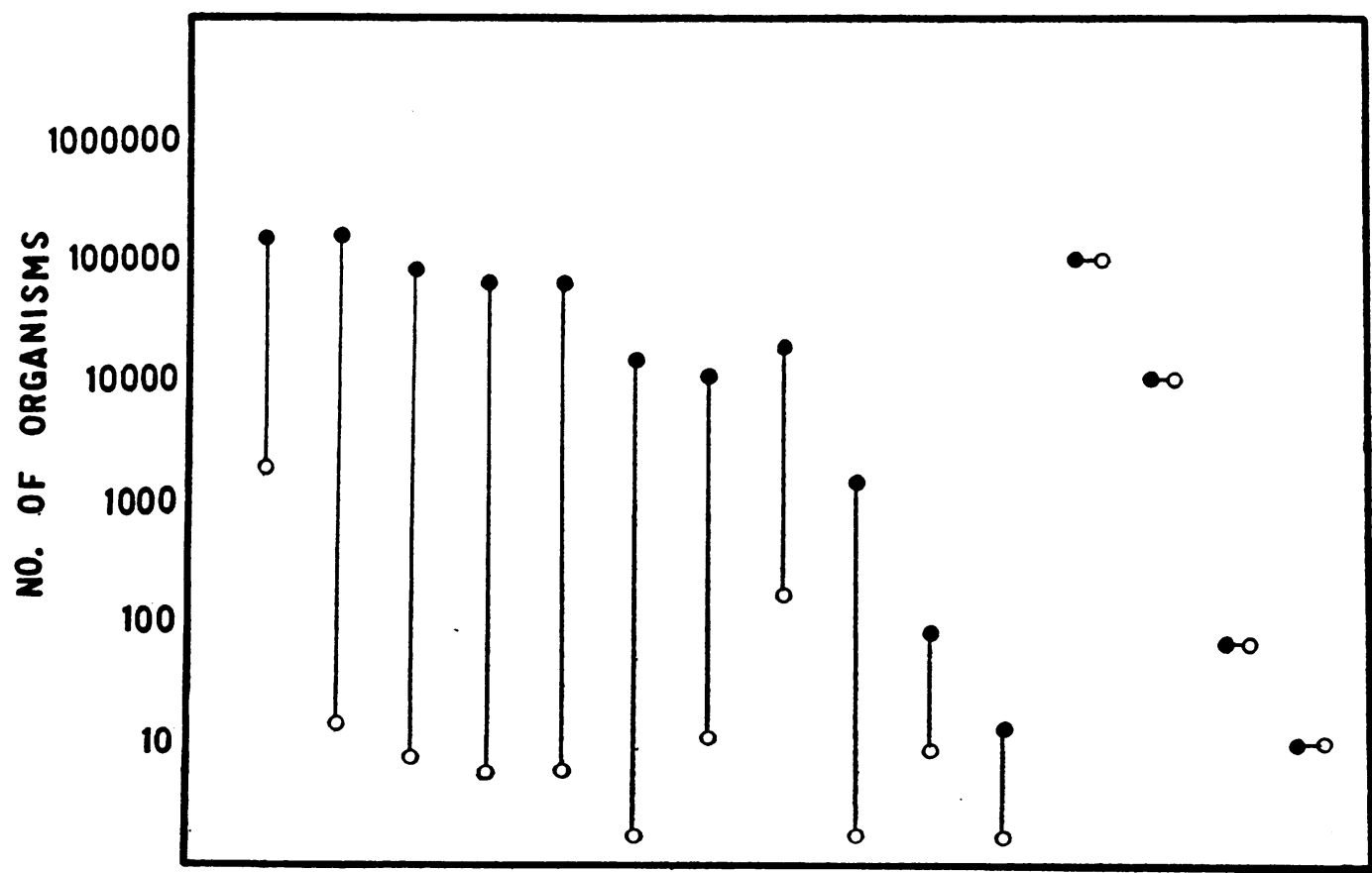

Fig. 1. The Effect of Adding Mucin to Whole Blood of Patients with Gonococcal Arthritis

The solid circles indicate the maximum number of organisms which were killed by $0.5 \mathrm{cc}$. of whole blood. The open circles indicate the maximum number of organisms killed by the same blood following the addition of mucin. 
TA BLE I

The addition of veal infusion broth or mucin to blood with effect on bactericidal power

\begin{tabular}{l|c|c|c|c|c|c|c|c}
\hline \hline & $10^{-1}$ & $10^{-2}$ & $10^{-2}$ & $10^{-4}$ & $10^{-8}$ & $10^{-8}$ & $10^{-7}$ \\
\hline Whole blood & + & 0 & 0 & 0 & 0 & 0 & 0 \\
Whole blood with mucin & + & + & + & + & 0 & 0 & 0 \\
Whole blood with broth & 0 & 0 & 0 & 0 & 0 & 0 & 0 \\
\hline
\end{tabular}

$$
\begin{aligned}
+ & =\text { growth } \\
0 & =\text { no growth }
\end{aligned}
$$

activity. This is not the case when a substance such as veal infusion broth is added.

\section{The effect of adding mucin to blood on the titer of complement}

As we have already related, gonococci are killed in vitro by lysis, and this is accomplished by the combined action of complement and specific antibody. From the experiments just presented, it was gathered that the additions of mucin to blood with a high bacteriolytic titer interfered with bacteriolysis. To test whether this was due to an inhibition of the action of complement, the titer of complement in the blood was studied before and after the addition of mucin. The results in 6 cases are shown in Table II, and it is plain that mucin had no effect on the complement titer of the blood, nor did it interfere with its action.

TABLE II

The effect of adding mucin to blood on the titer of complement

\begin{tabular}{c|c|c}
\hline & \multicolumn{2}{|c}{ Complement titer } \\
number & $\begin{array}{c}\text { Blood } \\
\text { serum }\end{array}$ & $\begin{array}{c}\text { Blood serum with } \\
\text { mucin added }\end{array}$ \\
\cline { 2 - 3 } & $c c$. & $c c$. \\
1 & .03 & .03 \\
2 & .03 & .03 \\
3 & .04 & .04 \\
4 & .05 & .04 \\
5 & .03 & .03 \\
6 & .03 & .03 \\
7 & .03 & .03 \\
\hline
\end{tabular}

The effect of adding mucin to whole defibrinated blood containing antigonococcal serum

Since it has been shown that the addition of antigonococcal serum to whole defibrinated blood increases the bacteriolytic titer (5), the effect of adding mucin to blood and antiserum was investigated.

The blood of 3 individuals was tested. In one series of tubes, $0.5 \mathrm{cc}$. of whole defibrinated blood and $0.1 \mathrm{cc}$. of varying dilutions of suspensions of organisms were used; in a second series, $0.5 \mathrm{cc}$. of whole blood, $0.1 \mathrm{cc}$. of a 1:40 dilution of antigonococcal horse serum, and $0.1 \mathrm{cc}$. of organisms; and in a third series, $0.5 \mathrm{cc}$. of whole blood, 0.1 cc. of a 5 per cent suspension of mucin, and 0.1 cc. of a 24-hour growth of organisms. The results are summarized in Table III.

TABLE III

The effect of adding mucin to whole blood containing immune serum

\begin{tabular}{|c|c|c|c|c|c|c|c|c|}
\hline & \multicolumn{7}{|c|}{ Dilution of organisms } & \multirow{2}{*}{$\begin{array}{c}\begin{array}{c}\text { Number } \\
\text { of } \\
\text { organisms }\end{array} \\
10^{-7}\end{array}$} \\
\hline & $10^{-1}$ & $10^{-2}$ & $10^{-3}$ & $10^{-4}$ & $10^{-8}$ & $10^{-8}$ & $10^{-7}$ & \\
\hline $\begin{array}{l}\text { CAsE } 1 \\
\text { Whole blood } 0.5 \mathrm{cc} \text {. } \\
\text { Organisms } 0.1 \mathrm{cc} \text {. }\end{array}$ & + & + & + & + & 0 & 0 & 0 & 3 \\
\hline $\begin{array}{l}\text { Whole blood } 0.5 \mathrm{cc} \text {. } \\
\text { Organisms } 0.1 \mathrm{cc} \text {. } \\
\text { Mucin } 0.1 \mathrm{cc} \text {. }\end{array}$ & + & + & + & + & + & + & $\mathbf{0}$ & 3 \\
\hline $\begin{array}{l}\text { Whole blood } 0.5 \mathrm{cc} \text {. } \\
\text { Organisms } 0.1 \mathrm{cc} \text {. } \\
\text { Immune serum } 0.1 \mathrm{cc} \text {. }\end{array}$ & + & 0 & 0 & 0 & 0 & 0 & 0 & 3 \\
\hline $\begin{array}{l}\text { Whole blood } 0.5 \mathrm{cc} \text {. } \\
\text { Organisms } 0.1 \mathrm{cc} . \\
\text { Immune serum } 0.1 \mathrm{cc} \text {. } \\
\text { Mucin } 0.1 \mathrm{cc} \text {. }\end{array}$ & + & + & + & + & 0 & 0 & 0 & 3 \\
\hline $\begin{array}{l}\text { Cass } 2 \\
\text { Whole blood } 0.5 \mathrm{cc} \text {. } \\
\text { Organisms } 0.1 \mathrm{cc} \text {. }\end{array}$ & + & + & + & + & + & + & + & 3 \\
\hline $\begin{array}{l}\text { Whole blood } 0.5 \mathrm{cc} \text {. } \\
\text { Organisms } 0.1 \mathrm{cc} \text {. } \\
\text { Mucin } 0.1 \mathrm{cc} \text {. }\end{array}$ & + & + & + & + & + & + & + & 3 \\
\hline $\begin{array}{l}\text { Whole blood } 0.5 \mathrm{cc} \text {. } \\
\text { Organisms } 0.1 \mathrm{cc} \text {. } \\
\text { Immune serum } 0.1 \mathrm{cc} \text {. }\end{array}$ & + & + & 0 & o & 0 & 0 & 0 & 3 \\
\hline $\begin{array}{l}\text { Whole blood } 0.5 \mathrm{cc} \text {. } \\
\text { Organisms } 0.1 \mathrm{cc} \text {. } \\
\text { Immune serum } 0.1 \mathrm{cc} \text {. } \\
\text { Mucin } 0.1 \mathrm{cc} \text {. }\end{array}$ & + & $t$ & + & + & 0 & $\mathbf{0}$ & 0 & 3 \\
\hline $\begin{array}{l}\text { CAsE } 3 \\
\text { Whole blood } 0.5 \mathrm{cc} \text {. } \\
\text { Organisms } 0.1 \mathrm{cc} \text {. }\end{array}$ & + & + & + & + & + & + & + & 3 \\
\hline $\begin{array}{l}\text { Whole blood } 0.5 \mathrm{cc} \text {. } \\
\text { Organisms } 0.1 \mathrm{cc} \text {. } \\
\text { Mucin } 0.1 \mathrm{cc} \text {. }\end{array}$ & + & + & + & + & + & + & + & 3 \\
\hline $\begin{array}{l}\text { Whole blood } 0.5 \mathrm{cc} \text {. } \\
\text { Organisms } 0.1 \mathrm{cc} \text {. } \\
\text { Immune serum } 0.1 \mathrm{cc} \text {. }\end{array}$ & + & + & + & 0 & 0 & 0 & 0 & 3 \\
\hline $\begin{array}{l}\text { Whole blood } 0.5 \mathrm{cc} \text {. } \\
\text { Organisms } 0.1 \mathrm{cc} . \\
\text { Immune serum } 0.1 \mathrm{cc} \text {. } \\
\text { Mucin } 0.1 \mathrm{cc} \text {. }\end{array}$ & + & + & + & + & 0 & 0 & 0 & 3 \\
\hline
\end{tabular}

It is evident that the addition of immune serum to whole blood enhanced its bactericidal power. When mucin was added, the bacteriolytic action was depressed but not abolished. This would suggest that antibody was operative even in the presence of mucin.

These experiments thus show that the bac- 
teriolytic titer of whole defibrinated blood can be enhanced by the addition of immune serum. When mucin is added, the bacteriolytic power is depressed but not abolished, and in a few cases it was not possible to demonstrate any interference with bactericidal action of antibody. This is what one might expect from the other experiments with whole blood without the addition of immune serum, and from the experiments of Miller and Castles who were able to show that antimeningococcal serums protected mice effectively against many times the minimal fatal dose of meningococci suspended in mucin. These latter experiments clearly indicate that antibodies are active and operative in the presence of mucin in vitro and in vivo, although there is evidence that their action is interfered with in part by the presence of mucin. We have found, in common with Miller and Castles, that synovial fluid which contains large amounts of mucin may fail to support the growth of gonococci. In our experience, this has been due to the excellent bactericidal power of the synovial fluid which is operative in the presence of mucin. The details of a comparative study of the bactericidal power of the synovial fluid and blood in gonococcal arthritis were presented in the previous paper (1).

To supplement the observations on the effect of mucin on bacteriolysin and to explain certain inconsistent results from the addition of mucin to whole blood, the problem was studied in another way. It was conceivable that the failure of mucin to depress bactericidal action in all samples was due to the presence of an excess of antibody, or there may have been some differences in the behavior of the different strains which were tested. To determine the importance of these two factors, additional experiments were carried out.

It has been known for some years that the blood serum of rabbits is bactericidal for the gonococcus, and we have been able to confirm this finding repeatedly. The effects of adding mucin to rabbits' blood were tested. Inasmuch as the experiments differed as to details, the methods will be described with each experiment.

\section{The effect of adding mucin to rabbits' blood on its bactericidal action}

Varying numbers of different strains of gonococci were added to $0.5 \mathrm{cc}$. of rabbits' whole blood, sealed in a pyrex tube, and incubated for 24 hours at $37^{\circ} \mathrm{C}$. The tubes were rotated constantly during that time. Another series of tubes was included which contained $0.5 \mathrm{cc}$. of rabbits' blood, $0.1 \mathrm{cc}$. of 5 per cent suspension of mucin, and a varying number of organisms. This mixture was incubated for the same length of time. The tubes were then opened and the contents of all tubes were cultured. An example of an experiment is shown in Table IV and the results of a study of 11 different strains are recorded in Figure 2.

TABLE IV

Example of experiment in which mucin was added to rabbits' blood

\begin{tabular}{|c|c|c|c|c|c|c|c|}
\hline \multirow{2}{*}{ Observation } & \multicolumn{6}{|c|}{ Dilution of organisms } & \multirow{2}{*}{$\frac{\begin{array}{c}\text { Number } \\
\text { of } \\
\text { organisms }\end{array}}{10^{-8}}$} \\
\hline & $10^{-1} \mid$ & $\mid 10-2$ & $10^{-3}$ & $10^{-6}$ & $10-8$ & $10-8$ & \\
\hline $\begin{array}{l}\text { Rabbits' blood } 0.5 \text { cc. } \\
\text { Organisms } 0.1 \text { cc. }\end{array}$ & & + & + & 0 & 0 & 0 & 6 \\
\hline $\begin{array}{l}\text { Rabbits' blood } 0.5 \text { cc. } \\
\text { Organisms } 0.1 \text { cc. } \\
\text { Mucin } 5 \text { per cent } 0.1 \text { cc. }\end{array}$ & + & + & + & 0 & 0 & 0 & 6 \\
\hline
\end{tabular}

The effect of adding mucin to rabbits blood and the growth of different strains of gonococci

The effect of adding mucin to rabbits' blood when different strains of organisms were added to the same sample of blood is shown in Figure 3. Varying numbers of 5 different strains of gonococci were added to $0.5 \mathrm{cc}$. of whole rabbits' blood derived from the same rabbit, and the maximum number of organisms killed by this amount of blood was determined. At the same time another series of tubes was set up containing the same amount of blood and organisms with the addition of $0.1 \mathrm{cc}$. of 5 per cent suspension of mucin. In 3 of the 5 strains tested in 2 different samples of rabbits' blood, there was a depression of the bactericidal action of the blood. This was taken to indicate that some of the differences observed when the mucin was added were due to the type of strain, and it could not be explained entirely on the basis of the variation of the antibody.

The next experiment was planned to test the effect of adding varying dilutions of immune serum to the same amount of blood with and without mucin. 


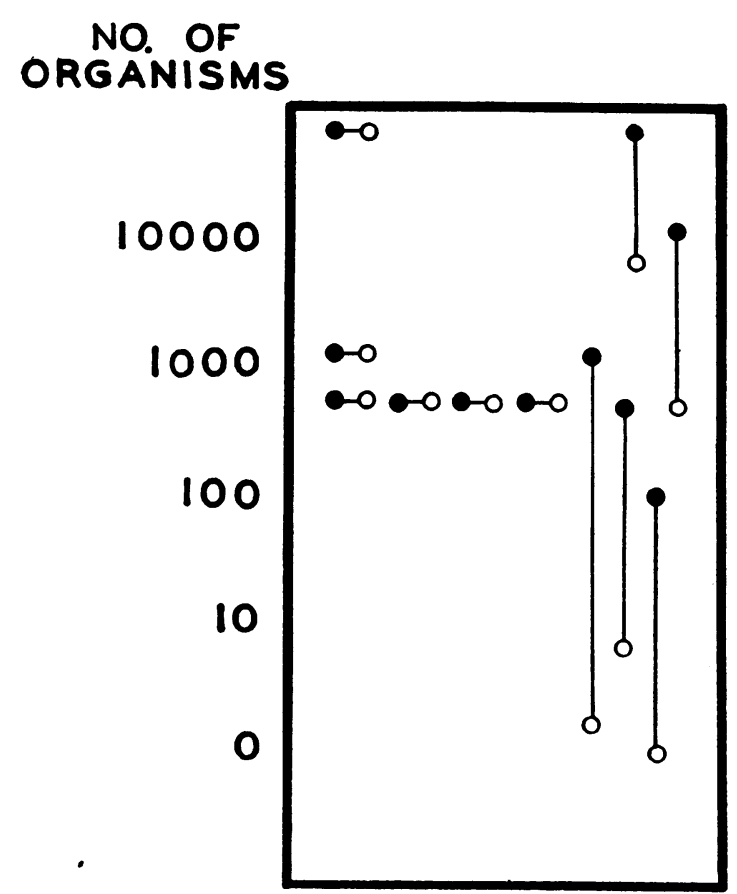

Fig. 2. Comparison of the Bacteriolytic Power of Whole Rabbits' Blood with and Without Mucin, Using 11 Different Strains of Gonococci

The solid circles indicate the maximum number of organisms killed by $0.5 \mathrm{cc}$. of blood without mucin; the open circles, the maximum number killed by $0.5 \mathrm{cc}$. of blood with $0.1 \mathrm{cc}$. of 5 per cent solution of mucin.

\section{The effect of adding mucin to rabbits' blood with varying amounts of immune serum}

The bactericidal power of the blood from 2 rabbits was determined for 2 different freshly isolated strains of gonococci. It may be observed in Table $\mathrm{V}$ that the addition of $0.1 \mathrm{cc}$. of a 5 per cent suspension of sterile mucin inhibited the bactericidal effect of the blood. When $0.1 \mathrm{cc}$. of a 1:40 dilution of immune serum was added to whole blood and organisms, the addition of mucin had little effect on inhibiting the bactericidal power of the blood. When less antibody was added in the form of higher dilutions of immune serum, the addition of mucin again inhibited the bacteriolytic effect of the blood. It would appear from these observations that the bactericidal effect of rabbits' blood mixed with mucin depends upon the amount of antibody present. That is to say, when the antibody titer is high, bactericidal action is operative even in the presence of mucin;

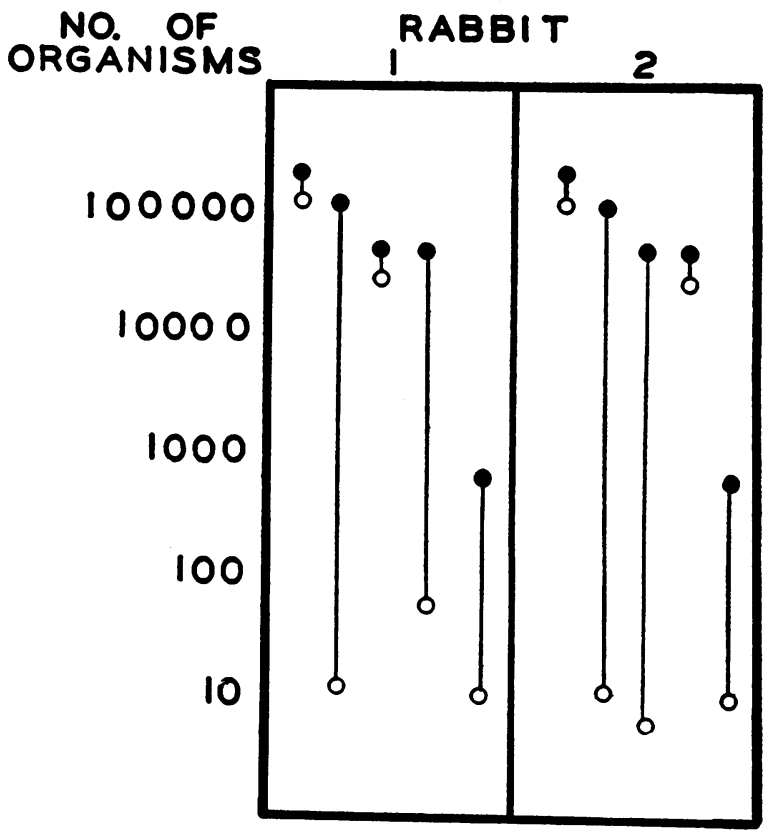

Fig. 3. Comparison of the Bacteriolytic Power of the Whole Blood, With and Without Mucin, of 2 Rabbits Using 5 Different Strains of Gonococci

The solid circles indicate the maximum number of organisms killed by $0.5 \mathrm{cc}$. of blood without mucin; the open circles, the maximum number killed with $0.1 \mathrm{cc}$. of 5 per cent solution of mucin.

when the titer is low, the bactericidal effect is altered by the presence of mucin.

\section{DISCUSSION}

These experiments indicate that the presence of mucin may inhibit the bacteriolytic action of serum containing antibodies against the gonococcus. This inhibition is not due to the depression of the titer of complement but, in some way as yet not clearly understood, mucin seems to protect the organism from the action of antibody and permits bacterial growth to take place. In the presence of large amounts of antibody, its action is operative in spite of the presence of mucin. There are also some differences when various strains are used in the same blood.

These observations may explain in part why organisms localize and thrive in some samples of synovial fluid in the face of high bactericidal power in the blood. That is to say, the presence of mucin in the synovial fluid aids the organisms in their growth, by protecting them from the ac- 
TABLE V

The effect of adding mucin to varying amounts of rabbits' whole blood with varying amounts of immune serum

\begin{tabular}{|c|c|c|c|c|c|c|c|c|c|c|c|c|c|c|c|}
\hline & \multirow{2}{*}{\multicolumn{7}{|c|}{$\begin{array}{c}\text { Without mucin } \\
\text { Dilution of organisms }\end{array}$}} & \multicolumn{7}{|c|}{ With 0.1 cc: 5 per cent mucin } & \multirow{3}{*}{$\frac{\begin{array}{c}\text { Number } \\
\text { of } \\
\text { organisms }\end{array}}{10^{-7}}$} \\
\hline & & & & & & & & \multicolumn{7}{|c|}{ Dilution of organisms } & \\
\hline & $10^{-1}$ & $10-2$ & $10^{-2}$ & $10^{-1}$ & $10^{-8}$ & $10-8$ & $10^{-7}$ & $10^{-1}$ & $10^{-2}$ & $10^{-2}$ & $10-4$ & $10^{-6}$ & $10-6$ & $10^{-7}$ & \\
\hline $\begin{array}{l}\text { Rabbit } 1 \\
\quad 0.3 \text { ce. whole blood }+ \\
0.1 \text { cc. organisass }\end{array}$ & ++++ & 0 & 0 & 0 & 0 & 0 & 0 & ++++ & ++++ & -+++ & ++++ & ++++ & 0 & 0 & 7 \\
\hline $\begin{array}{l}0.3 \text { co. Thole blood }+ \\
0.1 \text { oc. } 1 \text { : } 40 \text { immune serum }+ \\
0.1 \text { cc. organiams }\end{array}$ & ++++ & $\mathbf{0}$ & 0 & 0 & 0 & 0 & 0 & ++++ & ++++ & $\mathbf{0}$ & 0 & $\mathbf{0}$ & 0 & 0 & 7 \\
\hline $\begin{array}{l}0.3 \text { cc. Whole blood }+ \\
0.1 \text { oc. } 1: 80 \text { immune serum }+ \\
0.1 \text { cc. organisms }\end{array}$ & $\mathbf{0}$ & $\mathbf{0}$ & 0 & 0 & 0 & 0 & 0 & ++++ & ++++ & -++++ & $\mathbf{0}$ & $\mathbf{0}$ & $\mathbf{0}$ & 0 & 7 \\
\hline $\begin{array}{l}0.3 \mathrm{cc} \text {. whole blood }+ \\
0.1 \mathrm{cc} 1: 160 \text { immune serum }+ \\
0.1 \mathrm{cc} \text {. organisms }\end{array}$ & ++++ & 0 & $\mathbf{0}$ & 0 & 0 & 0 & $\mathbf{0}$ & ++++ & ++++ & ++++ & ++++ & 0 & 0 & 0 & 7 \\
\hline $\begin{array}{l}\text { Rabbit } 2 \\
0.2 \text { cc. Whole blood }+ \\
\quad 0.1 \text { oc. organisms }\end{array}$ & ++++ & ++++ & ++++ & 0 & 0 & 0 & 0 & ++++ & ++++ & ++++ & ++++ & ++++ & $+t+t$ & ++++ & 6 \\
\hline $\begin{array}{l}0.2 \text { co. whole blood }+ \\
0.1 \text { co. } 1: 40 \text { immune serum }+ \\
0.1 \text { co. organisms }\end{array}$ & ++++ & ++++ & 0 & 0 & 0 & 0 & 0 & ++++ & ++++ & ++++ & 0 & 0 & 0 & 0 & 6 \\
\hline $\begin{array}{l}0.2 \text { cc. whole blood }+ \\
0.1 \text { cc. } 1 \text { : } 80 \text { immune serum }+ \\
0.1 \text { co. organisms }\end{array}$ & ++++ & ++++ & 0 & 0 & 0 & 0 & 0 & ++++ & ++++ & ++++ & ++++ & 0 & 0 & 0 & 6 \\
\hline $\begin{array}{l}02 \text { ce. whole blood }+ \\
0.1 \text { cc. } 1 \text { : } 160 \text { immune serum }+ \\
0.1 \text { cc. organisms }\end{array}$ & ++++ & ++++ & ++++ & 0 & 0 & 0 & 0 & ++++ & ++++ & ++++ & ++++ & 0 & 0 & 0 & 6 \\
\hline $\begin{array}{l}0.2 \text { cc. whole blood }+ \\
0.1 \text { cc. } 1 \text { : } 320 \text { immune serum }+ \\
0.1 \text { cc. organisms }\end{array}$ & ++++ & ++++ & ++++ & 0 & 0 & 0 & 0 & ++++ & ++++ & ++++ & ++++ & ++++ & 0 & 0 & 6 \\
\hline
\end{tabular}

$t=$ growth

$0=$ no growth.

tion of antibody. The evidence so far would suggest that mucin was one of the environmental factors favoring the growth of the gonococcus, and its presence in different tissues may explain in part the peculiar localization of these organisms in the host.

In connection with the above observations, it is perhaps pertinent to recall the effect of other chemical substances which favor bacterial infection in animals and man by rupturing the local defense mechanism. The action of silica in enhancing the growth of tubercle bacilli (8) and the effect of calcium salts (9) in favoring the growth of hemolytic streptococci and anaerobic bacteria in tissues may be cited as examples. The results of experiments of this kind have been summarized recently by Topley (10). He points out that the analysis of the mechanisms by which these kataphylactic reactions are brought into being reveals that the exudate that is caused by the chemical provides excellent cultural conditions for the bacteria. In the case of lesions caused by streptococci following the injection of calcium or of tuberculous lesions following the injection of silica, it has been found that the vegetative activity of the organisms is greatly increased, and there is very active multiplication of the organisms.

Menkin (11) has demonstrated that when staphylococci are injected locally into the skin of rabbits, they are fixed less rapidly when urea is injected at the same time. This effect was attributed to the solvent action of urea on fibrin which permitted bacteria to spread to the lymphatics more readily.

It can be assumed, then, that certain conditions can be created in tissues by various chemicals which favor the growth and spread of bacteria. There is no question but that chemical reactions in the various tissues play an important rôle in determining whether or not bacteria will survive. Such reactions emphasize further the significance 
of the environment in aiding organisms to localize in certain areas of the body.

\section{SUMMARY AND CONCLUSIONS}

From a study of the effect of adding mucin to the whole blood of patients with gonococcal arthritis, of normal individuals, and of rabbits, the following conclusions are reached.

1. Mucin alone is a poor culture medium for the continuous growth of the gonococcus. These organisms are able to survive in this medium for as long as 28 hours at $37.5^{\circ} \mathrm{C}$.

2. The addition of "granular mucin" to whole defibrinated blood may depress the bacteriolytic titer for the gonococcus.

3. When mucin is added with a small amount of antigonococcal serum to whole blood, the bacteriolytic titer is reduced but not abolished. The bacteriolytic action of serum was shown to be operative to some degree even in the presence of mucin.

4. Mucin does not interfere with the action of complement or depress its potency.

5. These in vitro experiments suggest that mucin interferes with the sensitization of organisms by antibody.

6. The observations make it appear likely that mucin is a factor in favoring the localization and survival of gonococci in synovial fluid and the tendon sheaths.

\section{BIBLIOGRAPHY}

1. Spink, W. W., and Keefer, C. S., Studies of gonococcal infection. III. A comparison of the bactericidal properties of the synovial fluid and blood in gonococcal arthritis. J. Clin. Invest., 1937, 16, 17.

2. Miller, C. P., and Castles, R., Experimental meningococcal infection in the mouse. J. Infect. Dis., 1936, 58, 263.

3. Fothergill, L. D., Dingle, J. H., and Chandler, C. A., Studies on Haemophilus influenza. I. Infection of mice with mucin suspensions of the organism. J. Exper. Med., 1937, 65, 721.

4. Nungester, W. J., Jourdonais, L. F., and Wolf, A. A., The effect of mucin on infections by bacteria. $J$. Infect. Dis., 1936, 59, 11.

5. Spink, W. W., and Keefer, C. S., Studies of gonococcal infection. I. A study of the mode of destruction of the gonococcus in vitro. J. Clin. Invest., 1937, 16, 169.

6. Spink, W. W., and Keefer, C. S., Studies of gonococcal infection. II. The bacteriolytic power of the whole defibrinated blood of patients with gonococcal arthritis. J. Clin. Invest., 1937, 16, 177.

7. Miller, C. P., Some observations on experimental meningococcal infection. Tr. A. Am. Physicians, 1935, 50, 237.

8. Kettle, E. H., Experimental silicosis. J. Indust. Hyg. and Toxicol., 1926, 8, 491.

9. Kettle, E. H., Some aspects of inflammation and infection. I. and II. Lancet, 1927, 1, 1169 and 1225.

10. Topley, W. W. C., An Outline of Immunity. William Wood and Co. Baltimore, 1933, p. 248.

11. Menkin, V., Inflammation and bacterial invasiveness. Am. J. M. Sc., 1935, 190, 583. 